\title{
Performance of Brooders, Fry and Growth of the Nile Tilapia (Oreochromis niloticus) Cultured in an Experimental Recirculating Aquaculture System
}

\author{
José Luis Arredondo-Figueroa ${ }^{*}$, Laura Georgina Núñez-García ${ }^{2}$, Jesús T. Ponce-Palafox ${ }^{3}$, \\ Irene de Los Ángeles Barriga-Sosa1,2 \\ ${ }^{1}$ Unidad Acuícola, Departamento de Zootecnia, Universidad Autónoma de Aguascalientes, Aguascalientes, \\ México \\ ${ }^{2}$ Planta Experimental de Producción Acuícola, División de Ciencias Biológicas y de la Salud, Departamento de \\ Hidrobiología, Universidad Autónoma Metropolitana Iztapalapa, México, D.F., México \\ ${ }^{3}$ Centro de Innovación y Transferencia Tecnológica CENITT, Posgrado CBAP, Escuela Nacional de Ingeniería \\ Pesquera, Universidad Autónoma de Nayarit, Tepic, México \\ Email: ¡jlarredondo@correo.uaa.mx
}

Received 1 January 2015; accepted 20 September 2015; published 23 September 2015

Copyright (C) 2015 by authors and Scientific Research Publishing Inc.

This work is licensed under the Creative Commons Attribution International License (CC BY).

http://creativecommons.org/licenses/by/4.0/

(c) (i) Open Access

\begin{abstract}
We present results of a long-term study aimed to optimize Nile tilapia $O$. niloticus production in a recirculating aquaculture system (RAS) in México City. Three experiments were evaluated: 1) fry production; 2) production of masculinized fries; and 3) assessment of growth under three different densities $\left(10,30\right.$ and $\left.75 \mathrm{fish} / \mathrm{m}^{3}\right)$. The broodstock produced on average $2400 \pm 600$ fry every 15 days during six months, with a total production of $28,800 \pm 2000$. One hundred percent males were produced in 274-L raceways in an eight-week period. The obtained results in fish production in the RAS system indicated variations related to density. A daily growth rate of $3.6 \mathrm{~g} / \mathrm{day}$ was registered with a density of $10 \mathrm{fish} / \mathrm{m}^{3}, 0.9 \mathrm{~g} /$ day in $30 \mathrm{fish} / \mathrm{m}^{3}$ and $0.4 \mathrm{~g} / \mathrm{day}$ in $75 \mathrm{fish} / \mathrm{m}^{3}$. This information could be useful for production purposes in this type of systems.
\end{abstract}

\section{Keywords}

Tilapia, Oreochromis niloticus, Intensive Culture, Sex Reversal, Growth, Densities

\footnotetext{
${ }^{*}$ Corresponding author.
} 


\section{Introduction}

The production of tilapia in Mexico reached around 77,000 metric tons in 2009 representing an economic value of 26 million USA dollars [1], from this production approximately 4000 metric tons were produced in more than 1000 tilapia farms all over the country, and the rest was obtained in inland waters fisheries derived from aquaculture introduction actions [2]. Due to the volume and the economical value, tilapia is considered as one of the main fisheries in our country. During the last 20 years, inland water tilapia fisheries have stabilized at an annual production between 60,000 and 70,000 metric tons, and no production increase is expected in the near future. For this reason, tilapia culture is now increasing.

One of the species more cultured in Mexico is Nile tilapia (O. niloticus), and the availability of the basic consumables for production, such as commercial foods and masculinized fry, allow the development of numerous farms. Thus, in recent years, hormonal sexual reversion has been produced through the application of synthetic steroids such as 17- $\alpha$-methyltestosterone (MT) and Fluoxymesterone (FM) in the early stages of life, when the gonadic tissues are still undifferentiated [3] [4]. Masculinized fry are cultured under different technological levels and systems, such as small permanent dams, “jagüeyes”, ponds, concrete and liner-tanks, raceways and cage-nets. The commercial or table size of tilapia fluctuates according to the regional preferences of local consumers and, in general ranges from 50 up to $500 \mathrm{~g}$.

Recent studies on the culture of Nile tilapia O. niloticus under different experimental conditions in recirculating aquaculture systems (RAS) have been published, including the effects of different broodstock densities and reproductive performance [5]; the effects of light intensity and photoperiod on Nile tilapia reproduction [6]; stocking density and feeding levels on growth and feed efficiency [7]; dietary protein level on spawning performance [8]; performance of plastic biofilter media in water recirculation systems [9]; responses of reproduction with photoperiod manipulation [10]; effects of photoperiod on the performance of farmed Nile tilapia [11]; greenhouse experiments on growth and yield of tilapia in integrated rice-fish culture [12], and effects of photoperiod on growth and spawning efficiency [13], as well as on the design and improvement of a zero discharge [14] and on the treatment of recycled water, through the action of aquatic plants, such as Lolium multiflorum [15]; or wetlands [16]. However, there is scarce information describing the culture of Nile tilapia in RAS at all stages of its life cycle, from breeding up to production of table size harvests.

Thus, in the present study we characterized results of a long-term experiment aimed to optimize Nile tilapia $O$. niloticus production in a recirculating aquaculture system (RAS) in México City and under different phases of the species life cycle, from broodstock, proportion of male production and growth up to table-size.

\section{Materials and Methods}

Sixteen females and eight males of a Nile tilapia (O. niloticus) were introduced in a broodstock tank. One-yearold females and males with a mean body weight (BW) of $370 \pm 35.4 \mathrm{~g}$ and $462 \pm 23.5 \mathrm{~g}$ respectively, and a mean total length (TL) of $21.7 \pm 0.6 \mathrm{~cm}$, and $29.0 \pm 0.5 \mathrm{~cm}$, for females and males, respectively and maintaining a sex ratio of 2:1 female:male. Triplicate groups were stocked in three independent 3000-L circular tanks. The study was conducted during 180 days. Broodstock tanks were provided with biological filters, continuous aeration through an air compressor and a Titanium immersion 3000 watts heater. Fish were fed with a commercial tilapia diet (25\% crude protein, $5 \%$ lipids, and 5\% crude fibre) at a daily rate of $2 \%$ of total BW and twice a day (10:00 and 16:00 h). Fish were subjected to a 14L:10D (light: dark) photoperiod. Registration of water parameters included, temperature and dissolved oxygen (DO) were monitored daily with an oxymeter YSI model 550 A; whereas $\mathrm{pH}$, with a pHtestr20 Oaklon, and ammonia $\left(\mathrm{N}-\mathrm{NH}_{4}\right)$, nitrate $\left(\mathrm{N}-\mathrm{NO}_{3}^{-}\right)$, nitrite $\left(\mathrm{N}-\mathrm{NO}_{2}^{-}\right)$were recorded weekly with a HI83099 multiparameter photometer Hanna.

The performance indicators determined in each broodstock tank were: 1) number of spawns per female during six months; 2) total fry production in a six month period; 3) mean fry production every 15 days; 4) mortality (\%); 5) fry mean BW (g); 6) fry mean TL (mm); 7) monthly food consumed per breeder (g); 8) water flow per fish in $24 \mathrm{~h}$ (L/fish); 9) fry produced/accumulated water temperature in 15 days (total fry/ ${ }^{\circ} \mathrm{C}$ ); and 10) annual cost of food per breeder (USD cents).

Two thousand fry with a mean BW of $9.0 \pm 1.0 \mathrm{mg}$ and a mean TL of $1.0 \pm 0.01 \mathrm{~mm}$ were collected from broodstock tanks and introduced in 274-L hydraulic polyduct raceways $(274 \times 48 \times 20 \mathrm{~cm})(\mathrm{L} \times \mathrm{W} \times \mathrm{H})$, with three repetitions. Each raceway was provided with two cascade Aquaclear 200 filters, placed on both ends to keep a constant flow of $14 \mathrm{~L} / \mathrm{min}$ and a Titanium immersion heater Azzo (300 watts) to maintain water tem- 
perature.

Water parameters registered for fry raceways included: temperatures, dissolved oxygen (DO) were monitored daily, and $\mathrm{pH}$, ammonia $\left(\mathrm{N}-\mathrm{NH}_{4}\right)$, nitrate $\left(\mathrm{N}-\mathrm{NO}_{3}^{-}\right)$, nitrite $\left(\mathrm{N}-\mathrm{NO}_{2}^{-}\right)$weekly.

Fry were maintained in raceways for a period of eight weeks and fed daily ad libitum. Five daily rations were applied every two hours, starting at 9:00 and ending at 18:00 h. Feed was prepared with 5 mg of Fluoxymesterone (FM) per kilogram of meal-food with $47 \%$ of crude protein according to the methodology described by Jiménez and Arredondo [17].

The following indicators were determined: 1) initial mean BW (g); 2) final mean BW (g); 3) initial mean TL (mm); 4) final mean TL (mm); 5) mean BW gain in eight weeks (g); 6) water flow per fingerlings in 24 hours; 7) total feed consumed (g/fry/8 weeks); 8) feed conversion ratio (FCR); 9) mortality rate (\%); 10) specific growth rate (SGR, \%); 11) total biomass per raceway; 12) percentage of males; 13) total cost of food per fry during the eight weeks (USD cents).

Efficiency of sexual reversion was assessed by using two methodological approaches: 1) the aceto-carmine technique [18] was used in fish from all the experimental raceways conditions, 500 tilapia gonads pairs with a mean TL of $7.0 \mathrm{~cm}$ were evaluated. The second approach included histological analysis of 50 gonads pairs, conserved in Bouin solution, then dehydrated, cleared, perfuse, and paraffin-embedded $\left(49^{\circ} \mathrm{C}\right.$ to $50^{\circ} \mathrm{C}$ fusion point). Transversal $8 \mu \mathrm{m}$ deep cuts were done using a microtome, Microm model HM315 (Leica, Walldorf, Germany). Paraffin was removed from histological sections, stained with Harris hematoxylin-yellowish Eosin (H-E), and finally conserved in Merk's resin [19].

After the masculinization process, fingerlings were transferred to 5000-L circular-tanks where they remained during four months until them reaching a BW from 132 to $148 \mathrm{~g}$. Later on, they were translated to six 4000-L steel circular-tanks at three densities: 10,30 and $75 \mathrm{fish} / \mathrm{m}^{3}$, with two replicates to evaluate growth. The trial lasted 63 days. The tanks were connected to a recirculating aquaculture system (RAS) maintaining strong aeration and controlled temperature by means of an 18,000-watts Titanium immersion heater. Fishes were weighed and measured every 15 days up until the end of the evaluation process. Fishes were fed daily within $4 \%$ and $2 \%$ of total BW according to their sizes, with commercial food, Purina, Tilapia Chow with 25\% protein, 5\% lipids, and 5\% crude fibre (Ralston, Purina, Saint Louis Missouri, USA) in two rations at 10:00 and 15:00 h.

Water parameters including temperature and dissolved oxygen (DO) were monitored daily, and $\mathrm{pH}$, ammonia $\left(\mathrm{N}-\mathrm{NH}_{4}\right)$, nitrate $\left(\mathrm{N}-\mathrm{NO}_{3}^{-}\right)$, nitrite $\left(\mathrm{N}-\mathrm{NO}_{2}^{-}\right)$weekly.

The following indicators were determined: 1) mean initial BW (g); 2) mean final BW (g); 3) days of culture; 4) mean gain of BW (g); 5) daily growth (g/day); 6) total yield $\left(\mathrm{kg} / \mathrm{m}^{3}\right) ; 7$ ) specific growth rate $\left(\mathrm{SGR}_{\%}\right.$ day $\left.\left.^{-1}\right) ; 8\right)$ relative growth rate (RWR, \% day ${ }^{-1}$ ); 9) feed conversion ratio (FCR); 10) total harvest (kg); 11) total final harvest weighing more than $195 \mathrm{~g}(\mathrm{~kg}) ; 12$ ) total final harvest weighing less than $195 \mathrm{~kg}$ (kg); and 13) percentage of marketable size (\%), according to Hashim et al. [20].

Data were emptied on a spreadsheet and arithmetic means and measures of dispersion were calculated. Data were tested for the normality and variance homogeneity (Kolgomorov-Smirnov and Levene tests). One-way ANOVA was used to test data followed by post-hoc Tukey's test, to separate significantly different mean values. A significant level of 0.05 was retained for each test and frequency graphs were plotted with Statistica software version 3.0 (StatSoft, Tulsa, OK, USA).

\section{Results}

The broodstock tanks water quality parameters throughout the study showed the following values (mean values \pm standard deviation): water temperature $=28.2^{\circ} \mathrm{C} \pm 1.08^{\circ} \mathrm{C} ; \mathrm{DO}=6.3 \pm 0.65 \mathrm{mg} / \mathrm{L} ; \mathrm{pH}=7.8 \pm 0.19 ; \mathrm{N}^{-\mathrm{NH}_{4}}=$ $0.10 \pm 0.13 \mathrm{mg} / \mathrm{L} ; \mathrm{N}-\mathrm{NO}_{3}^{-}=3.4 \pm 0.1 \mathrm{mg} / \mathrm{L} ; \mathrm{N}-\mathrm{NO}_{2}^{-}=0.4 \pm 0.30 \mathrm{mg} / \mathrm{L}$.

Growth and performance indicators registered in broodstock tanks are shown in Table 1. Data indicate the adequateness of managing 16 females and 8 males in 5000-L circular-tanks maintaining a density of five breeders $/ \mathrm{m}^{3}$. The mean BW and TL values of breeders varied. In females, the BW ranged between 200 and $600 \mathrm{~g}$ and in males from 400 to $600 \mathrm{~g}$. With these breeder sizes and a 2:1 female: male relationship it was possible to obtain a mean production of 28,800 \pm 2000 fry in a six-month period, with a mean of $600 \pm 200$ fingerlings per female and six spawning per female in the same period.

The water quality register in the raceways were as follow: water temperature $=27.5^{\circ} \mathrm{C} \pm 0.20^{\circ} \mathrm{C}$; $\mathrm{DO}=6.6 \pm$ $0.30 \mathrm{mg} / \mathrm{L} ; \mathrm{pH}=7.3 \pm 0.10 ; \mathrm{N}-\mathrm{NH}_{4}=0.01 \pm 0.05 \mathrm{mg} / \mathrm{L} ; \mathrm{N}-\mathrm{NO}_{3}^{-}=7.6 \pm 3.07 \mathrm{mg} / \mathrm{L} ; \mathrm{N}-\mathrm{NO}_{2}^{-}=0.04 \pm 0.03$ $\mathrm{mg} / \mathrm{L}$. 
Table 1. Performance indicators (Mean values \pm S.D.) registered in the brooder tanks.

\begin{tabular}{cc}
\hline Indicators & Value \\
\hline $\begin{array}{c}\text { Number of spawns per female in six months } \\
\text { Total fry production in six months } \\
\text { Mortality (\%) }\end{array}$ & $6.0 \pm 1.0$ \\
Mean fry production every 15 days & $5.0 \pm 2.0$ \\
Fry, mean BW (g) & $2400 \pm 600$ \\
Fry, mean TL (mm) & $0.009 \pm 0.001$ \\
Monthly food consumed per brooder (g) & $1.0 \pm 0.01$ \\
Water flow per fish in 24 h (L/fish) & $112.5 \pm 10.42$ \\
Fry produced/accumulated temperature in 15 days (fry $\left./{ }^{\circ} \mathrm{C}\right)$ & $780 \pm 10.0$ \\
Annual cost of food per brooder (USD cents) & $5.7 \pm 0.02$ \\
\hline
\end{tabular}

The performance indicators obtained in this experiment are resumed in Table 2. Data showed the feasibility of producing $100 \%$ males-fries in eight weeks. In this period fries reached a BW of up to $1 \mathrm{~g}$ and a sex reversal efficiency of $100 \%$, this was confirmed by the aceto-carmine technique and the assessment of the histological slides of gonads. Figure 1(a) and Figure 1(b), depicts two microphotographs comparing both techniques. The growth tendency expressed in BW and TL was constant along the experimental period (Figure 2). The fry frequency with respect to BW at the end of the experiment indicates that it is possible to obtain $>90 \%$ of fry from 0.8 to up to $1 \mathrm{~g}$ (Figure 3 ).

The growout tanks presented the following water quality values throughout the study: water temperature $=$ $28.2^{\circ} \mathrm{C} \pm 1.89^{\circ} \mathrm{C} ; \mathrm{DO}=6.4 \pm 0.44 \mathrm{mg} / \mathrm{L} ; \mathrm{pH}=8.3 \pm 0.16 ; \mathrm{N}-\mathrm{NH}_{4}=0.07 \pm 0.19 \mathrm{mg} / \mathrm{L} ; \mathrm{N}-\mathrm{NO}_{3}^{-}=11.0 \pm 9.91$ $\mathrm{mg} / \mathrm{L} ; \mathrm{N}-\mathrm{NO}_{2}^{-}=0.05 \pm 0.07 \mathrm{mg} / \mathrm{L}$.

The results of the experiments of growout are shown in Table 3. Survival rate in all treatment was adequate closed at $100 \%$. Data indicates a variable growth rate that depends on density. Daily growth rate was affinity of density. The highest daily growth rate was registered in the lowest density with 3.6 g/day. The yields above marketable weight (>195 g) in the three tests were also variable, being higher at the lower density, followed by 30 and $75 \mathrm{fish} / \mathrm{m}^{3}$. Higher yield was obtained in high density with $52.6 \mathrm{~kg} / \mathrm{m}^{3}$.

\section{Discussion}

Previous experiments have demonstrated that the number of eggs per female, number of eggs per spawn, and number of spawning per female are significantly higher in a 12L:12D photoperiod and that inter-spawning intervals were also shorter [13]; although Campos-Mendoza et al. [10] mentioned 18L:6D as the best photo- period to produce larger amount of eggs and an improved total and relative fecundity in females. However, in this study it was possible to obtain a constant production of fingerlings under the mentioned controlled conditions. Victor [21] indicated that when Nile tilapia (O. niloticus) females reached maturity, they could have from 8 to 12 spawns per year, at water temperatures of up to $24^{\circ} \mathrm{C}$. In the present study, an average of six spawns per female were obtained during six months, with 28,800 \pm 2200 fingerlings, maintaining an average of $2400 \pm 600$ fingerlings every 15 days with 16 females.

Experiments realized in RAS demonstrated the feasibility of producing massive amounts of fingerlings, controlling the quality and density of breeders, providing adequate food, and maintaining the control of water quality, mainly water temperature and dissolved oxygen (DO), at a 14L:10D photoperiod [3] [4].

The BW of breeders is important to keep a high breeding rate. Tilapia females with high BW can produce more eggs per spawn than smaller ones; however, the smaller fish produce more eggs per BW unit. Little [22] indicated that Nile tilapia females with a mean BW of 200 g produce more fry than bigger females, and Smith et al. [23] reported that one-year-old females were significantly more productive than two-year-old ones. The bigger females keep more eggs and fry and have less spawning. This coincides with previous studies that suggest that one-year-old Nile tilapia is more adequate as breeders [5] [24] [25]. 
Table 2. Performance indicators (Mean values \pm S.D.) registered in masculinized raceways.

\begin{tabular}{cc}
\hline Indicators & Value \\
Initial mean BW (g) & $0.009 \pm 0.001$ \\
Final mean BW (g) & $1.4 \pm 5.0$ \\
Initial mean TL (mm) & $0.9 \pm 0.1$ \\
Final mean TL (mm) & $45.0 \pm 1.2$ \\
Mean gain BW in eight weeks (g) & $1.39 \pm 0.45$ \\
Water flow per fry in 24 h & $6.72 \pm 1.02$ \\
Total feed consumed (g/fry in 8 weeks) & $2.24 \pm 0.05$ \\
Feed Conversion Ratio (FCR) & $1.6 \pm 0.2$ \\
Mortality (\%) & $3.0 \pm 1.0$ \\
Specific Growth Rate (SGR \%) & $0.6 \pm 0.1$ \\
Total biomass per raceway (g) & $2800 \pm 300$ \\
Percentage of males (\%) & 100 \\
Total cost of feed per fry during 8 weeks (USD cents) & $0.013 \pm 0.03$ \\
\hline
\end{tabular}

Table 3. Performance indicators obtained in the fish tanks in 63 days of culture.

\begin{tabular}{|c|c|c|c|c|}
\hline \multirow{2}{*}{ Indicators $^{1}$} & \multicolumn{4}{|c|}{ Stocking density (fish/m³) } \\
\hline & 10 & 30 & 75 & \pm S.E. $^{2}$ \\
\hline Mean initial BW (g) & $134^{\mathrm{a}}$ & $132^{\mathrm{a}}$ & $148^{\mathrm{a}}$ & 5.07 \\
\hline Mean final BW (g) & $345^{c}$ & $187.5^{\mathrm{b}}$ & $170.2^{\mathrm{a}}$ & 0.57 \\
\hline Survival (\%) & $100^{\mathrm{a}}$ & $99^{\mathrm{a}}$ & $100^{\mathrm{a}}$ & 0.33 \\
\hline Mean gain of BW (g) & $228^{c}$ & $55.5^{\mathrm{b}}$ & $22.2^{\mathrm{a}}$ & 0.57 \\
\hline Mean gain of BW (\%) & $195.8^{\mathrm{c}}$ & $42.0^{\mathrm{b}}$ & $15.0^{\mathrm{a}}$ & 0.57 \\
\hline Daily growth (g/day) & $3.6^{\mathrm{b}}$ & $0.9^{\mathrm{a}}$ & $0.4^{\mathrm{a}}$ & 0.33 \\
\hline Total yield $\left(\mathrm{kg} / \mathrm{m}^{3}\right)$ & $4^{\mathrm{a}}$ & $5.8^{\mathrm{a}}$ & $13.2^{\mathrm{b}}$ & 0.57 \\
\hline Specific Growth Rate (SGR, \% day ${ }^{-1}$ ) & $1.72^{\mathrm{b}}$ & $0.58^{\mathrm{a}}$ & $0.22^{\mathrm{a}}$ & 0.17 \\
\hline Feed Conversion Ratio (FCR) & $1.24^{\mathrm{a}}$ & $1.58^{\mathrm{b}}$ & $1.4 \mathrm{a}^{\mathrm{b}}$ & 0.06 \\
\hline Total harvest (kg) & $16.0^{\mathrm{a}}$ & $23.1^{\mathrm{b}}$ & $52.6^{c}$ & 0.58 \\
\hline Total final harvest weighing more than 195 g (kg) & $15.5^{\mathrm{a}}$ & $14.0^{\mathrm{a}}$ & $20.0^{\mathrm{b}}$ & 0.58 \\
\hline Total final harvest weighing less than195 g (kg) & $0.5^{\mathrm{a}}$ & $9.1^{\mathrm{b}}$ & $32.6^{c}$ & 0.47 \\
\hline Percentage of marketable size (\%) & $100.0^{\mathrm{c}}$ & $60.6^{\mathrm{b}}$ & $38.0^{\mathrm{a}}$ & 0.58 \\
\hline
\end{tabular}

${ }^{1}$ Different superscript in row means significantly differences $(\mathrm{p}>0.05) .{ }^{2} \pm$ S.E. $=$ Standard Error.

The results obtained in this study showed the advantages of using one-year-old females and males. It must also be considered that fry production is variable, and depends on the BW of the females, as well as on the female:male sex ratio. In this sense, it is recommend maintain a 2:1 ratio in 5000-L tanks in RAS, and a density of 5 breeder $/ \mathrm{m}^{3}$ for constant fry production with a mean mortality of $5 \%$. The annual cost of food per breeder was under 1 USD, obtaining a higher cost-benefit relationship due the large amount of fry that can be produced in this system.

Siddiqui and Al-Harbi [26] found a higher production of fry by maintaining a female to male ratio of 3:1 and $2: 1$, and a density of two breeder $/ \mathrm{m}^{2}$, being the one-year-old females the most productive ones at $28^{\circ} \mathrm{C}$ water temperature. Rhida and Cruz [5] found that a broodstock at $4 \mathrm{fish} / \mathrm{m}^{2}$ yielded a better fingerlings production, 


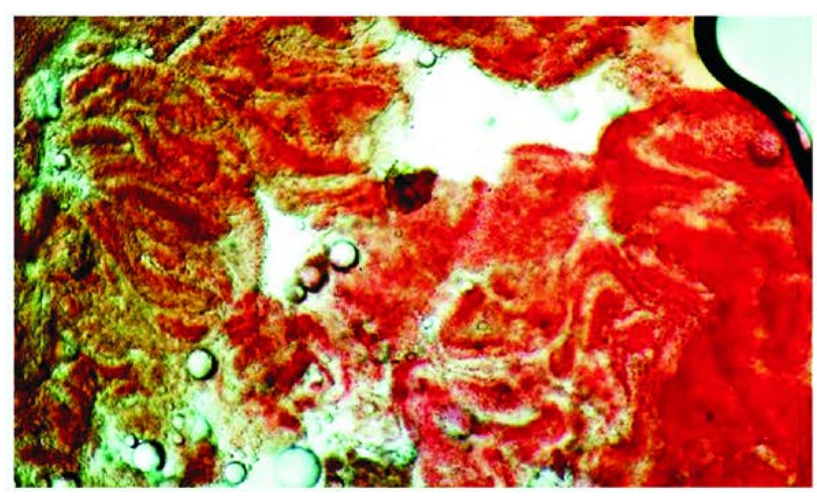

(a)

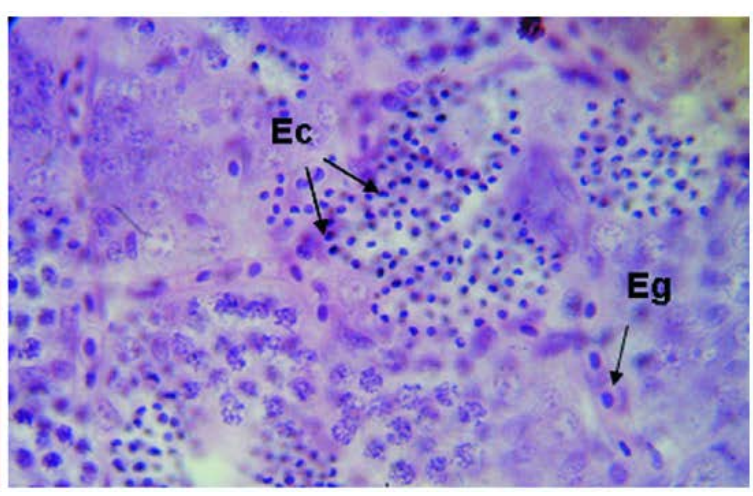

(b)

Figure 1. Confirmation of sex reversal process: (a) male identified by the aceto-carmine technique showing the testicles; (b) male identified by histological probes: spermatogonies (Eg) and spermatocytes (Ec) can be observed.

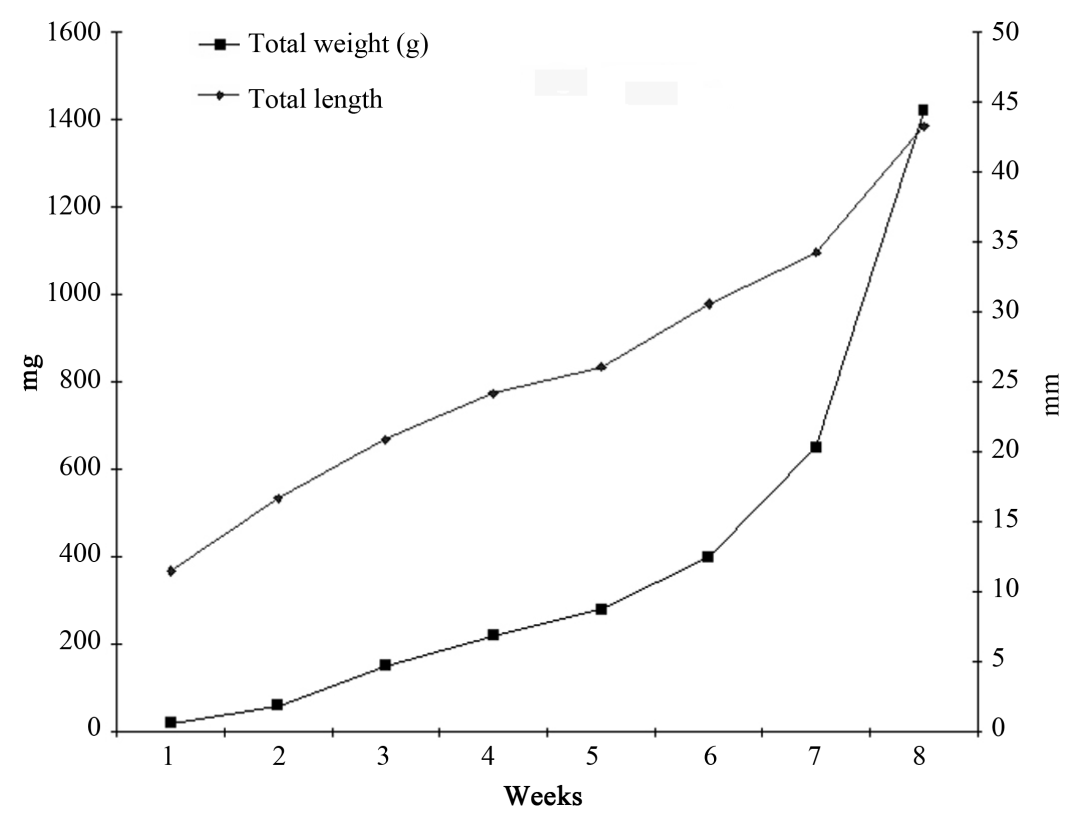

Figure 2. Fry growth expressed in BW (mg) and LT (mm) during the sex reversal process.

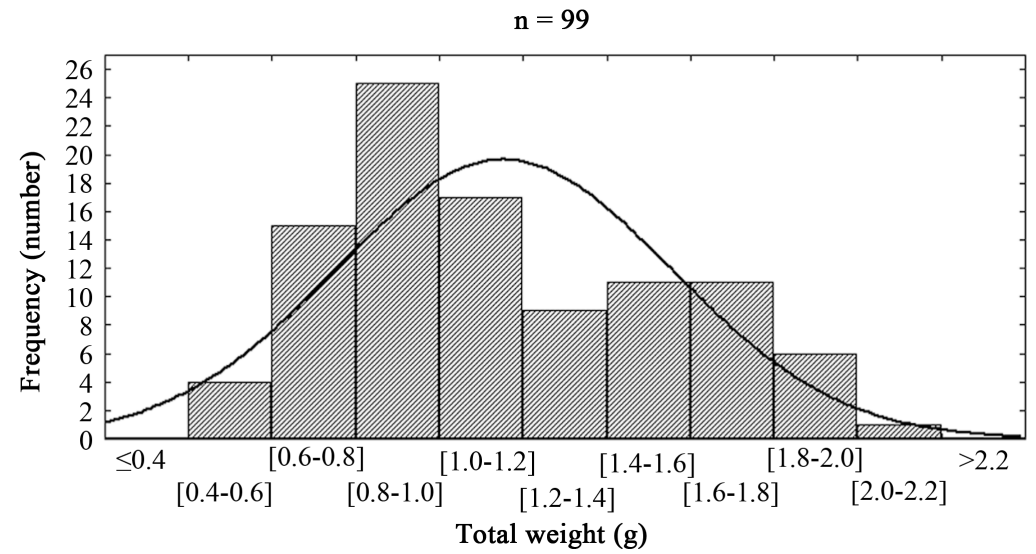

Figure 3. Graph of frequency (number of observations) with respect to the intervals of total weight of masculinized fry after eight weeks culture. 
maintaining a constant water temperature of $29^{\circ} \mathrm{C} \pm 1^{\circ} \mathrm{C}$. In addition, Rhida and Cruz [6] reported that breeders stocked at a rate of $8 \mathrm{fish} / 0.4 \mathrm{~m}^{3}$, with a male to female ratio of 1:3, at different light intensities and photoperiods, had a synchrony in spawning and the percentage of sac and swimming fry stages were significantly higher at 2500 lux/18h day treatment. Campos-Mendoza et al. [10] found significantly larger eggs under normal day length (12L:12D) as compared with other treatment groups. However, fish reared under long day length (18L:6D) exhibited higher total fecundity and relative fecundity, with a reduction in inter-spawn-intervals.

The data obtained in this study show a relationship between the accumulated temperature in 15 days and the number of fingerlings produced in broodstock tanks under controlled conditions. If water temperature is maintained at $29^{\circ} \mathrm{C}$ this relationship reaches a value of 5.7, if the temperature drops the value decreases. This indicator would be considered in future investigations.

The raceways constitute an excellent alternative to produce massive quantities of masculinized fry of $O$. niloticus. As indicated, in Table 2, at high densities (7.2 fingerlings/L) and at $27.5^{\circ} \mathrm{C}$ of water temperature, the specific growth rate (SGR) was in average, $0.6 \%$, and the mean BW gained reached $1.4 \mathrm{~g}$ in eight weeks with ad libitum feeding. El-Sayed [7] reported an optimum density and feeding rate of five fingerlings/L and $30 \%$ of BW daily. The results differed from those reported by this last author with the advantage of managing a higher number of fingerlings when they were feeding ad libitum during the experimental period. This represented a consumption of $2.2 \mathrm{~g}$ in the whole period with a relatively cheaper cost of 77 fry of $1 \mathrm{~g}$ BW per 1 USD.

Previous experiences demonstrated that sexual reversion was more effective when fry with a mean BW of 10 mg and a mean TL of $9.5 \mathrm{~mm}$ [3]-[17] were used, similarly to those used in this work. Hiott and Phelps [27] obtained a $96 \%$ efficiency of sex reversal in fingerlings with a mean TL of $11 \mathrm{~mm}$, and this efficiency decreased when age and size increased.

Analysis through the aceto-carmine technique and the histology of gonads showed that $100 \%$ of sampled fishes were males. This might have resulted from the following factors: 1) an adequate preparation of hormonal food; 2) the raceways allowed for a good water exchange and quality, avoiding microalgae growth; 3) feed frequency of at least five times per day; 4) frequent cleaning of raceways, retrieving faeces and wastes; and 5) controlled water temperature.

The advantages of massive production of fry in raceways are: 1) the system permits to keep a constant water flow during $24 \mathrm{~h}$; 2) stabilized water quality, maintaining water temperature and high DO levels; 3) food containing high protein content $(>40 \%$ ) maintained higher growth rate, as mentioned by El-Sayed et al. [8].

The growout experiment showed a direct relationship between density and final average BW. At low density $\left(10 \mathrm{fish} / \mathrm{m}^{3}\right)$ the final mean of BW was of $345 \mathrm{~g}$, and $100 \%$ of fishes reached a marketable size; in contrast, in high density $\left(75 \mathrm{fish} / \mathrm{m}^{3}\right)$ Nile tilapia reached a final mean BW of $170.2 \mathrm{~g}$. Densities of $30 \mathrm{fish} / \mathrm{m}^{3}$ presented an intermediary value of $187.5 \mathrm{~g}$ in 63 days. However, all fishes in all treatments reached at least $150 \mathrm{~g}$, independently from the initial size, rearing time and density, which can be considered as a table-size in our country. This information is of great value to elaborate production strategies considering an elastic and changing tilapia market in Mexico, since the regional demand of tilapia size vary and depends on consumer preferences and market niches.

Some data indicate that a density near to 200 fishes $/ \mathrm{m}^{3}$ in net-cages is adequate [20], which coincides with Cruz and Rhida [28]. Both works mentioned the water quality and diet composition and quality as fundamental variables to reach a successful tilapia culture. Levels of $28 \%$ to $30 \%$ of crude protein are adequate, although, in some cases, higher values of crude protein at high densities are preferred. The RAS growout experiments demonstrated an excellent growth rates at high densities, while keeping an adequate flow and quality of water, foods containing $25 \%$ crude protein, and a feeding frequency appropriate to the size of fishes. The total harvest obtained in the RAS demonstrated the feasibility to produce high quantities of tilapia biomass using $100 \%$ male's populations.

\section{Conclusion}

Optimized Nile tilapia production in a recirculating aquaculture system (RAS) in México City was achieved. This information can be of use for production purposes in this type of systems. An average production of $2400 \pm$ 600 fry/15days during six months, with a total production of 28,800 \pm 2000 with a broodstock of 16 females and eight males of 1 year of age was obtained, and 100\% reversed males were produced in 274-L raceways in an eight-week period. A daily growth rate of $3.6 \mathrm{~g} /$ day was registered at a density of $10 \mathrm{fish} / \mathrm{m}^{3}$, obtaining $100 \%$ of 
commercial size, in a density of $30 \mathrm{fish} / \mathrm{m}^{3}$ daily growth rate reached $0.9 \mathrm{~g} /$ day with $60.6 \%$ of marketable size, and finally, in $75 \mathrm{fish} / \mathrm{m}^{3}$ was of $0.4 \mathrm{~g} /$ day with $38.0 \%$ of fish table size.

\section{Acknowledgements}

The authors thank Dr. Guillermo A. Blancas-Arroyo and the Experimental Biologist Mireya Martínez-Legaria for their cooperation in these projects. Financial support was provided by the División de Ciencias Biológicas y de la Salud, UAM-Iztapalapa.

\section{References}

[1] Comisión Nacional de Acuacultura y Pesca, and Secretaría de Agrícultura, Ganadería, Desarrollo Rural. Pesca y Alimentación (2009) Anuario Estadístico de Acuacultura y Pesca 2009. CONAPESCA, SAGARPA, México.

[2] Comisión Nacional de Acuacultura y Pesca, and Secretaría de Agrícultura, Ganadería, Desarrollo Rural, Pesca y Alimentación (2013) Carta Nacional Acuícola. CONAPESCA, SAGARPA, DOF 9 de Septiembre 2013, México.

[3] Jiménez-Badillo, M.L. and Arredondo-Figueroa, J.L. (2000) Effect of Oral Treatment of Synthetic Androgens on Sex Ratio, Survival and Growth Rates, in Three Strains of Tilapia. Hidrobiológica, 10, 115-120.

[4] Moreno, E.A., Rodríguez, C.A., Barriga, S.I.A. and Arredondo, F.J.L. (2003) Producción de Tilapia del Nilo (Oreochromis niloticus) masculinizada con la hormona fluoximesterona en sistemas cerrados de recirculación (in Spanish with English Abstract). In: Anonymous, Ed., Memorias del Congreso Iberoamericano Virtual de Acuicultura (CIVA 2003), Zaragoza, España, 77-87.

[5] Rhida, M.T. and Cruz, E.M. (1999) Effect of Different Broodstock Densities on the Reproductive Performance of Nile tilapia, Oreochromis niloticus (L.), in a Recycling System. Aquaculture Research, 30, 203-210. http://dx.doi.org/10.1046/j.1365-2109.1999.00311.x

[6] Ridha, M.T. and Cruz, E.M. (2000) Effect of Light Intensity and Photoperiod on Nile Tilapia Oreochromis niloticus L. Seed Production. Aquaculture Research, 31, 609-617. http://dx.doi.org/10.1046/j.1365-2109.2000.00481.x

[7] El-Sayed, A.-F.M. (2002) Effects of Stocking Density and Feeding Levels on Growth and Feed Efficiency of Nile Tilapia (Oreochromis niloticus L.) fry. Aquaculture Research, 33, 621-626. http://dx.doi.org/10.1046/j.1365-2109.2002.00700.x

[8] El-Sayed, A.-F.M., Mansour, C.R. and Ezzat A.A. (2003) Effects of Dietary Protein Level on Spawning Performance of Nile Tilapia (Oreochromis niloticus) Broodstock Reared at Different Water Salinities. Aquaculture, 220, 619-632. http://dx.doi.org/10.1016/S0044-8486(02)00221-1

[9] Al-Hafed, Y.S., Alam A., and Alam, M.A. (2003) Performance of Plastic Biofilter Media with Different Configuration in a Water Recirculation System for the Culture of Nile Tilapia (Oreochromis niloticus). Aquaculture Engineering, 29, 139-154. http://dx.doi.org/10.1016/S0144-8609(03)00065-7

[10] Campos-Mendoza A., McAndrew, B.J., Coward, K. and Bromage, N. (2004) Reproductive Response of Nile Tilapia (Oreochromis niloticus) to Photoperiodic Manipulation; Effects on Spawning Periodicity, Fecundity and Egg Size. Aquaculture, 231, 299-314. http://dx.doi.org/10.1016/j.aquaculture.2003.10.023

[11] El-Sayed, A.-F.M. and Kawanna, M. (2004) Effects of Photoperiod on the Performance of Farmed Nile Tilapia Oreochromis niloticus: I. Growth, Feed Utilization and Survival of Fry and Fingerlings. Aquaculture, 231, 393-402. http://dx.doi.org/10.1016/j.aquaculture.2003.11.012

[12] Frei, M. and Becker, K. (2005) A Greenhouse Experiment on Growth and Yield Effects in Integrated Rice-Fish Culture. Aquaculture, 244, 119-128. http://dx.doi.org/10.1016/j.aquaculture.2004.11.014

[13] El-Sayed, A.-F.M. and Kawanna, M. (2007) Effects of Photoperiod on Growth and Spawning Efficiency of Nile Tilapia (Oreochromis niloticus L.) Broodstock in Recycling System. Aquaculture Research, 38, 1242-1247. http://dx.doi.org/10.1111/j.1365-2109.2007.01690.x

[14] Shnel, N., Bakar, Y., Ezer, T., Dafni, Z. and Van Rijn, J. (2002) Design and Performance of a Zero-Discharge Tilapia Recirculating System. Aquaculture Engineering, 26, 191-203. http://dx.doi.org/10.1016/S0144-8609(02)00013-4

[15] Pan, J., Shao, Z., Miao, X. and Cui, S. (2004) Treatment of Recirculated Wastewater from Tilapia Culture Tank by Using Lolium multiflorum Lam of NFT Culture. Journal of Agronomy and Environmental Science, 23, 148-150.

[16] Zachritz, W.H., Hanson, A.T., Sauceda, J.A. and Fitzsimmons, K.M. (2008) Evaluation of Submerged Surface Flow (SSF) Constructed Wetlands for Recirculating Tilapia Production Systems. Aquaculture Engineering, 39, 16-23. http://dx.doi.org/10.1016/j.aquaeng.2008.05.001

[17] Jiménez, B.M.L. and Arredondo, F.J.L. (2000) Manual de técnicas para inducir la reversión sexual en tilapia. Universidad Autónoma Metropolitana Unidad Iztapalapa, México, D.F. 
[18] Wasserman, G.J. and Afonso, L.O.B. (2002) Validation of the Aceto-Carmin Technique for Evaluating Phenotypic Sex in Nile Tilapia (Oreochromis niloticus) Fry. Ciencia Rural, 32, 113-139. http://dx.doi.org/10.1590/S0103-84782002000100023

[19] Di Fiore, M.S.H. (1981) Diagnóstico histológico: síntesis actualizada de histología teórica y práctica y reconocimiento de los tejidos y órganos por su estructura microscópica. Octava Edición, El Ateneo, Buenos Aires.

[20] Hashim, R.S., Chong, C.A., Fatan, N.A., Layman, N. and Ali, A. (2002) Production of Hybrid Red Tilapia, Oreochromis mossambicus $\times$ O. niloticus at Varying Stocking Densities in Portable Canvas Tanks. Journal of Applied Aquaculture, 12, 1-12. http://dx.doi.org/10.1300/J028v12n03 01

[21] Victor, S.A. (1999) Recent Advances in Tilapia Broodstocks Management. Proceedings Acuicultura-99, Puerto La Cruz, November 17-19 1999, 9-16.

[22] Little, D.C. (1989) An Evaluation of Strategies for Production of Nile Tilapia Oreochromis niloticus (L.) Aliveness Suitable for Hormonal Treatment. PhD Thesis, Institute of Aquaculture, University of Stirling, Stirling.

[23] Smith, S.J., Watanabe, W.O., Chan, J.R., Ernst, D.H., Wicklund, R.I. and Olla, B.L. (1991) Hatchery Production of Florida Red Tilapia Seed in Brackish Water Tanks: The Influence of Broodstocks Age. Aquaculture Research, 22, 141147. http://dx.doi.org/10.1111/j.1365-2109.1991.tb00504.x

[24] Siraj, S.S., Smitherman, R.O., Castillo-Galluser, S. and Dunham, R.A. (1983) Reproductive Traits for Three-Year Classes of Tilapia niloticus and Maternal Effects on Their Progeny. In: Fishelson, L. and Yaron, Z., Eds., Proceedings of the International Symposium on Tilapia in Aquaculture, Tel Aviv, 8-13 May 1983 , 210-218.

[25] Watanabe, W.O. and Kuo, C.M. (1985) Observations on the Reproductive Performance of Nile Tilapia (Oreochromis niloticus) in Laboratory Aquaria at Various Salinities. Aquaculture, 49, 315-323. http://dx.doi.org/10.1016/0044-8486(85)90088-2

[26] Siddiqui, A.Q. and Al-Harbi, A.H. (1997) Effects of Sex Ratio, Stocking Density and Age of Hybrid Tilapia on Seed Production in Concrete Tanks in Saudi Arabia. Aquaculture International, 5, 207-216. http://dx.doi.org/10.1023/A:1018383201054

[27] Hiott, E.A. and Phelps, P.R. (1993) Effects of Initial Age and Size on Sex Reversal of Oreochromis niloticus Fry Using Methyltestosterone. Aquaculture, 112, 301-308. http://dx.doi.org/10.1016/0044-8486(93)90391-B

[28] Cruz, E.M. and Ridha, M. (1991) Production of Tilapia Oreochromis spilirus Günther, Stocked at Different Densities in Sea Cages. Aquaculture, 99, 95-103. http://dx.doi.org/10.1016/0044-8486(91)90290-N 